Ataturk Üniversitesi Veteriner Bilimleri Dergisi

\title{
The Relationship Between Animal-Originated Food Demand and Income Growth in Turkey
}

\section{Berrin ŞENTÜRK ${ }^{1 凶}$}

1. Ondokuz Mayıs University, Faculty of Veterinary Medicine, Department of Livestock Economics and Management, Samsun, TURKEY.

\begin{abstract}
The aim of this study was to examine the effect of national income level (per capita) on demand of animaloriginated food products in Turkey. The data from national income per capita, demography and consumption of major livestock products (cattle and buffalo meat, sheep and goat meat, poultry meat, and cow, sheep, goat and buffaloes milk) were evaluated for the period of 2003-2012 years. The consumption level of animal-originated food products was determined by using situation analysis. Correlation analysis was used in the study and the relation between income and animal originated food consumption was found significant $(P<0.01)$. In conclusion, the demand of animal-originated food has increased depending on the income increase in Turkey.
\end{abstract}

Key words: Consumption, Income, Meat, Situation analysis.

\section{Türkiye'de Hayvansal Kaynaklı Gıda Ürünleri Talebi ile Gelir Artışı Arasındaki ilişki}

Özet: Bu çalışmanın amacı, Türkiye'de kişi başına düşen ulusal gelir düzeyinin hayvansal orjinli gıda talebi üzerine olan etkisini incelemektir. Çalışmada 2003-2012 yıllarına ait kişi başına düşen ulusal gelir, demografik veriler, önemli hayvansal orjinli ürünlerin tüketimi verileri incelenmiştir (sığır ve manda eti, koyun ve keçi eti, kanatlı eti, inek, koyun, keçi ve manda sütü). Hayvansal orjinli gıda ürünlerinin tüketim seviyesi durum analizi ile belirlenmiştir. Gelir ve hayvansal orjinli ürün tüketimi arasındaki ilişki korelasyon analizi ile değerlendirilmiştir ve gelirle hayvansal orjinli gıda tüketimi arasındaki ilişki anlamlı bulunmuştur $(\mathrm{P}<0.01)$. Sonuç olarak, Türkiye'de hayvansal orjinli gıda talebinin gelir artışına bağıı olarak arttığı tespit edilmiştir.

Anahtar kelimeler: Durum analizi, Et, Gelir, Tüketim. 


\section{INTRODUCTION}

D

ue to increasing the demand of livestock products driven by urbanisation rate, the levels of income grow in parallel with the human population increase (Delgado, 2005). The demand changes the country's livestock farmer profile, social and cultural structures, expectations of society, regulations of the value chain, religious beliefs. Macroeconomic development level of countries affects the livestock production systems and will continue later. Proper macroeconomic trends and high national income per capita will increase the demand of animal-originated food products (Delgado et al., 1999; Steinfeld et al., 2006; Thornton, 2010; FAO, 2011). Turkey's gross domestic product is $\$ 4.559$ per capita in 2003 and it has exceeded \$ 10.497 per capita in 2012 (Ministry of Economics, 2014). Between 2001 and 2012, annual per capita income was increased approximately $50 \%$.

According to the data from the World Bank, countries are classified as low-income, lower middle, upper middle and high-income countries. Turkey's income level is upper middle in 2010 (FAO, 2011). Developed country people annual per capita consumption is $78 \mathrm{~kg}$ meat and $202 \mathrm{~kg}$ milk in 2002, while trends of $83 \mathrm{~kg}$ meat and $203 \mathrm{~kg}$ milk are projected in 2015. The same trends in developing countries apply, as $28 \mathrm{~kg}$ meat and $44 \mathrm{~kg}$ milk in 2002 and $32 \mathrm{~kg}$ meat and $55 \mathrm{~kg}$ milk in 2015, respectively (Stenfield, 2003; FAO, 2006; Stenfield et al., 2006a). There have been marked changes in livestock structure and animal-originated product demand (Cranfield et al., 1998; Stenfield et al., 2006b; Lundström, 2011) over the world.

The aim of this study was therefore to examine the effect of national income level (per capita) on demand of animal-originated food products.

\section{MATERIALS and METHODS}

The material of this study was obtained from the required data from Food and Agricultural Organisation of the United Nations (FAO), Turkish
Statistical Institute (TUIK) and Ministry of Economics in Republic of Turkey. Data from TUIK population, The Ministry of Economics gross national products and FAO's animal-originated food demands were used in the calculations.

Situation analysis was used in the study. The key drivers of the study were gross national product per capita, demographic data on total population, major animal products amount and per capita consumption of animal-originated food products were examined by considering the years of 20032012 data.

The quantities of animal-originated food product per capita were calculated by dividing the major animal-originated food product (beef, cow milk, chicken meat and sheep-goat meat) amounts to the total population of Turkey.

The increase in national income (including the period of ten years) whether it affects the demand of food from animal source or not was investigated in the study.

According to the technical acceptance, there was no export and import of animal products in the term considered.

Null hypothesis of the study was determined as; there would be no relationship with the gross national income increase and per capita consumption of animal-originated food products.

\section{Statistical Analysis}

Descriptive statistics (Means and Standard deviations) per capita on the national income, consumption of beef, cow milk, chicken meat and sheep-goat meat and correlation of the national income and consumption of beef, cow milk, chicken meat and sheep-goat meat were considered and Spearman Correlation test was used in the study by using SPSS 20 software programme (SPSS, 2013).

\section{RESULTS}

Data form Turkey's population and gross national products (GDP) per capita were given in Table 1. There in, years of 2003 were accepted as an 
index year, and the change of the national income per capita and population data were also given.

Table 1. Turkey's population and gross domestic product per capita.

Tablo 1. Türkiye'de nüfus ve kişi başına düşen gayri safi milli hasıla.

\begin{tabular}{ccccc}
\hline Year & $\begin{array}{c}\text { Income } \\
\text { (US\$) }\end{array}$ & Index & Population & Index \\
\hline 2003 & 4.559 & 100 & 66.873 .000 & 100 \\
\hline 2004 & 5.764 & 126 & 67.734 .000 & 101 \\
\hline 2005 & 7.022 & 154 & 68.582 .000 & 103 \\
\hline 2006 & 7.586 & 166 & 69.421 .000 & 104 \\
\hline 2007 & 9.240 & 203 & 70.586 .000 & 106 \\
\hline 2008 & 10.438 & 229 & 71.517 .100 & 107 \\
\hline 2009 & 8.559 & 188 & 72.561 .312 & 109 \\
\hline 2010 & 10.022 & 220 & 73.722 .988 & 110 \\
\hline 2011 & 10.466 & 230 & 74.724 .269 & 112 \\
\hline 2012 & 10.497 & 230 & 75.627 .384 & 113 \\
\hline Index* 2003=100. & & &
\end{tabular}

The national income of Turkey in 2012, as compared with that in 2003, has increased by approximately 50\%. Annual GDP per capita was growing at $13 \%$ while the annual population growth being at $1.3 \%$. The highest growth rates of GDP per capita in were realized 2008, 2011 and 2012.

Data on the consumption of major animaloriginated food product ( $\mathrm{kg} /$ capita/year) was calculated as the amounts of animal-originated foods supply divided by the population between 2008 and 2012 and some part of the data was taken from the FAO database. These data and growth rate of major animal-originated products (i.e. beef, cow milk, sheep and goat milk and chicken meat) were given in Table 2.

Data for 2008-2012 was calculated in this study and for 2003-2007 it was driven from FAO' database. As seen in the table, increasing of animal product consumption beef became the first in place. Per capita consumption of beef was increased by about 50\% from 2008-2012.

Table 2. Annual consumption of major animal-originated food products (kg/capita/year).

Tablo 2. Önemli hayvansal orjinli gıda ürünlerinin yıllık tüketimi (kg/kişi başı/yı).

\begin{tabular}{ccccccccc}
\hline Year & Beef & Index & Cow milk & Index* & Sheep and Goat Meat & Index* & Chicken Meat & Index * \\
\hline 2003 & 4.40 & 100 & 101 & 100 & 4.70 & 100 & 13.00 & 100 \\
\hline 2004 & 5.40 & 123 & 101 & 100 & 4.70 & 100 & 12.90 & 99 \\
\hline 2005 & 4.70 & 87 & 105 & 104 & 4.60 & 98 & 13.30 & 103 \\
\hline 2006 & 4.90 & 104 & 112 & 107 & 4.60 & 100 & 14.70 & 111 \\
\hline 2007 & 6.10 & 124 & 113 & 101 & 4.60 & 100 & 14.40 & 98 \\
\hline 2008 & 5.18 & 85 & 157 & 139 & 4.46 & 97 & 15.20 & 106 \\
\hline 2009 & 4.48 & 125 & 160 & 102 & 4.12 & 92 & 17.83 & 117 \\
\hline 2010 & 8.39 & 129 & 168 & 105 & 3.71 & 90 & 19.58 & 110 \\
\hline 2011 & 8.63 & 103 & 185 & 110 & 3.94 & 106 & 21.59 & 110 \\
\hline 2012 & 10.56 & 122 & 211 & 114 & 4.24 & 108 & 22.79 & 106 \\
\hline Index* 2003=100 & & & & & & &
\end{tabular}


Descriptive statistics on the study parameters were given in Table 3.

Table 3. Descriptive statistics of research parameters.

Tablo 3. Araştırma parametrelerinin tanımlayıcı istatistikleri.

\begin{tabular}{lccc}
\hline & $\mathrm{N}$ & Mean & $\begin{array}{c}\text { Standard } \\
\text { Deviation }\end{array}$ \\
\hline Income & 10 & 8415.30 & 2119.79 \\
\hline Beef & 10 & 6.27 & 2.15 \\
\hline $\begin{array}{l}\text { Chicken } \\
\text { meat }\end{array}$ & 10 & 16.53 & 3.67 \\
\hline $\begin{array}{l}\text { Cow milk } \\
\text { Sheep and } \\
\text { goat meat }\end{array}$ & 10 & 141.30 & 39.86 \\
\hline $\begin{array}{l}\text { Valid N } \\
\text { (list wise) }\end{array}$ & 10 & 4.37 & 3.47 \\
\hline
\end{tabular}

The average per capita Gross Domestic Product was 8415 U.S. \$ in ten years period.

Using Spearman Correlation test, the relationship between the income and major animaloriginated food was compared and the results were given in Table 4.

Table 4. Correlation of income and consumption of animal-originated food.

Tablo 4. Hayvansal orjinli gıdaların tüketimi ve gelir arasındaki korelasyon.

\begin{tabular}{lcc}
\hline & $\mathrm{n}$ & $\mathrm{r}$ \\
\hline Income-beef & 10 & $0.782^{* *}$ \\
\hline Income-cow milk & 10 & $0.936^{* *}$ \\
\hline Income-chicken meat & 10 & $0.903^{* *}$ \\
\hline $\begin{array}{l}\text { Income-sheep and goat } \\
\text { meat }\end{array}$ & 10 & $-0.775^{* *}$ \\
\hline${ }^{* * P<0.01 .}$ & & \\
\hline
\end{tabular}

The Sig. 2-tailed level was .000 showing that there was a significance between the interest in income and chicken meat consumptions and the relationship was positive $90.3 \%$. This means that as the value of one variable goes up or down so will the other one. In evaluations, based on the observation of the correlation coefficient, a numberof $10-15$ of them was expected to be above
0.71. In this study, the relationship of income-cow milk and income-chicken meat were strong, while the income-beef and income sheep and goat meat relationships were medium.

\section{DISCUSSION and CONCLUSION}

Data from the present findings showed that Turkey's annual population growth rate was $1.3 \%$, while GDP growth rate being $13 \%$ between $2003-$ 2012 years. In the same period, the animaloriginated food consumption level increased twofold except for sheep and goat meat and it seems that this trend will continue. Poultry production systems were the fastest growing sector and per capita chicken meat consumption was $13 \mathrm{~kg}$ in 2003 and it reached $22.79 \mathrm{~kg}$ in 2012 . In the same period, per capita annual consumption of cow milk was increased two-fold. Beef consumption was $4.40 \mathrm{~kg}$ in 2003 and it increased 2.11 fold in 2012.

There were strong positive correlations between the income and annual per capita cow milk and chicken meat consumptions. The null hypothesis of the study is rejected. People income increased in the last decade and, hence, the consumption of cow milk and chicken meat increased $(P<0.05)$.

The annual per capita meat consumption (beef, pork, chicken, sheep and goat) ofdeveloping countries was $28 \mathrm{~kg}$, while the milk consumption was $44 \mathrm{~kg}$ in 2002 (Stenfield et al., 2006a). In developed countries, the annual per capita meat consumption was $78 \mathrm{~kg}$ in 2002, while milk consumption was $202 \mathrm{~kg}$ in the same year (Thornton, 2010). Turkey's annual per capita meat (beef, chicken, sheep and goat) consumption was $22.10 \mathrm{~kg}$, while milk consumption was $101 \mathrm{~kg}$ in 2003. In 2000's, Turkey's meat consumption was less than those in both developed and developing countries. In the projection of FAO (2006), annual per capita meat consumption in developing countries will be $32 \mathrm{~kg}$, while milk consumption will be $55 \mathrm{~kg}$ in 2015. In developed countries, the annual per capita meat consumption will be $83 \mathrm{~kg}$, while 
milk consumption to be203 $\mathrm{kg}$ inthe same year. Turkey's meat consumption was $37.59 \mathrm{~kg}$, while milk consumption was $202 \mathrm{~kg}$ in 2012. According to data from the 2002, Turkey's meat consumption increased and passed the level of developing countries and also milk consumption increased as similar to that of developed countries.

As the income of Turkish people has increased, animal-originated food consumption also increased in the studied period. Undoubtedly, Turkey's urban population is growing and animal-originated food consumption needs of urban people will increase in the next decade. Indeed, in a previous study, the correlation between income and food expenditures was found positive, such that the family'sincome increased theanimal-originated food expenditure from $39.62 \%$ to $53.78 \%$ (Ghafoor et al., 2012).

In conclusion, when people's income increases, their consumption of animal-originated food also increases. This trend goes on up to a certain level so it is expected that the investments in animal sector would favourably affect the livestock sector and have a positive return.

\section{REFERENCES}

Cranfield JAL., Hertel TW., Eales JS., Preckel PV., 1998. Changes in the structure of global food demand. American Journal of Agricultural Economics, 80, 1042-1050.

Delgado C., Rosegrant M., Steinfeld H., Ehui S., Courbois C., 1999. 'Livestock to 2020: the next food revolution' Discuss Paper 28. 2020 Vision Initiative Food, Agriculture and Environment. International Food Policy Research Institute.

Delgado C., 2005. Rising demand for meat and milk in developing countries: implications for grasslands-based livestock production. "In Grassland: a global resource", Ed., DA. Mc Gilloway, 29-39, The Netherlands: Wageningen Academic Publishers.

Food and Agricultural Organization (FAO), 2011. Mapping supply and demand for animal-source foods to 2030. FAO Animal Production and Health Working Paper No.2, E-ISBN 978-92-5-
107041-3 (PDF).

Food and Agricultural Organization (FAO), 2006. World agriculture: towards 2030/2050. Interim report, global perspective studies unit. Rome, Italy: food and agriculture organization.

Ghafoor A., Arshad IA., Sheikh AW., 2012. Variation in consumption pattern and calories among different income groups. Science International (Lahore), 24, 317-321.

Lundström M., 2011. Dynamics of the livestock revolution: marginalization and resistance in Southern Brazil. Journal of Sustainable Agriculture, 35, 208-232.

Ministry of Economy Republic of Turkey, 2014. Economic Outlook, March, 2014.

SPSS, 2013. SPSS for Windows, Version 20. SPSS Inc. New York.

Steinfeld H., Wassenaar T., Jutzi S., 2006a. Livestock production systems in developing countries: status, drivers, trends. Scientific and Technical Review of the Office International des Epizooties, 25, 505-516.

Steinfeld H., 2003. Economic constraints on production and consumption of animal source foods for nutrition in developing countries. Journal of Nutrition, 133 (11 Suppl 2), 4054S4061S.

Steinfeld H., Gerber P., Wassenaar T., Castel V., Rosales M., Haan C., 2006b. Livestock's long shadow: environmental issues and options. Rome: FAO.

Thornton PK., 2010. Livestock production: recent trends, future prospects. Philophosical Transactions of the Royal Society B Biological Sciences, 365, 2853-2867. 